\title{
Quercetin and kaempherol: an argument against the use of podophyllin?
}

\author{
Carsten Sand Petersen, Kaare Weismann
}

Department of

Dermatology,

Gentofte Hospital,

DK-2900 Hellerup,

Denmark

C S Petersen

Department of

Dermato-Venereology,

Bispebjerg Hospital,

University of

Copenhagen,

Denmark

K Weismann

Correspondence to: Carsten Sand Petersen, MD

Department. of

Dermatology, Gentoft

Hospital, DK-2900

Hellerup, Denmark.

Accepted for publication

10 August 1994

\begin{abstract}
Introduction-Topical application of podophyllin is a routine procedure in patients with ano-genital warts. Podophyllin is a crude plant extract and is therefore not a well-defined product. It may contain variable amounts of the active lignan podophyllotoxin and the majority of the dry weight of podophyllin is made up of substances never identified. Objective-The purpose of the study was to estimate in podophyllin $20 \%$ the amounts of two mutagenic substances, quercetin and kaempherol.

Methods-Using high-pressure liquid chromatography the amounts of quercetin and kaempherol were determined in 3 batches of podophyllin $20 \%$.

Results-Quercetin and kaempherol constitutes $2 \cdot 5-3 \cdot 8 \%$ and $6 \cdot 0-6 \cdot 4 \%$ of podophyllin dry substance, respectively. Podophyllotoxin constitutes in comparison $12 \cdot 7-13 \cdot 8 \%$ of podophyllin dry substance.

Conclusion-As approximately $10 \%$ of the amount of dry substance in podophyllin $20 \%$ is composed of two mutagenic flavonoids, quercetin and kaempherol, efforts should be focused on the production of a well-defined purified podophyllotoxin preparation that may replace podophyllin for clinic use in patients with genital warts. Self-medication with purified podophyllotoxin $0.5 \%$ may be considered as first-line treatment in well-instructed patients with external genital warts.
\end{abstract}

(Genitourin Med 1995;71:92-93)

Keywords: podophyllin, quercetin, kaempherol

\section{Introduction}

It is widely accepted that drugs used in human medicine should ideally contain welldefined active substances shown in controlled clinical trials to be effective and safe in the licensed indications. However, since the 1940s a routine treatment for condyloma acuminatum has been topically applications of $20-25 \%$ podophyllin in ethanol, a crude mixture of cytotoxic materials from plant resins originating from either of two podophyllum species: Podophyllum peltatum and Podophyllum emodi. ${ }^{1}$ The most important ingredient of podophyllin, quantitatively and therapeutically, is podophyllotoxin. ${ }^{23}$ Podophyllin contains in addition a number of other lignans including alpha-peltatin, beta-peltatin and 4dime-thylpodophyllotoxin. ${ }^{4}$

Part of the color of podophyllin is due to the presence of a flavonoid-pigment called quercetin. ${ }^{67}$ Quercetin (3,31, $4^{1}, 5,7$-pentahydroxy-flavone) occurring in conjugated forms in many plant products has been shown to be a highly mutagenic substance. ${ }^{8}$ In order further to characterize podophyllin we quantitatively estimated the content of quercetin and another mutagenic flavonoid kaempherol $\left(3,4^{1}, 5,7 \text {-tetrahydroxyflavone }\right)^{9}$ in three batches of podophyllin $20 \%$.

\section{Methods}

The analyses were carried out by means of a high-pressure liquid chromatography (HPLC) - system consisting of Schimadzu LC-6A liquid chromatograph, SPD-6AV UVVIS detector, SCL-6B system controller and an C-R5A integrator. The column was a steel column with Spherisorb S3 ODS $1(100 \times$ $4.6 \mathrm{~mm}$ diameter) and the mobile phase consisted of methanol, $\mathrm{H}_{2} \mathrm{O}$ and phosphoric acid in the ratio 450:545:5. The UV detection was performed at $370 \mathrm{~nm}$. As standards quercetin R8, quercetin dihydrate (Art. 17196-4 Aldrich), kaempherol RS, kaempherol (Art. 60010, Fluka) were used.

Results

In the table it can be seen that quercetin composes $2,5-3,8 \%$ of the dry substance of podo-

The content of two mutagenic flavonoids, quercetin and kaempherol, determined in 3 batches of podophyllin $20 \%$

\begin{tabular}{|c|c|c|c|c|c|c|}
\hline & \multicolumn{6}{|c|}{ Podophyllin $20 \%$} \\
\hline & \multicolumn{2}{|l|}{ Batch No 1} & \multicolumn{2}{|l|}{ Batch No 2} & \multicolumn{2}{|c|}{ Batch No 3} \\
\hline & $\begin{array}{l}\text { Percentage } \\
\text { of weight } \\
\text { of solution }\end{array}$ & $\begin{array}{l}\text { Percentage } \\
\text { of podophyllin } \\
\text { dry substance }\end{array}$ & $\begin{array}{l}\text { Percentage } \\
\text { of weight } \\
\text { solution }\end{array}$ & $\begin{array}{l}\text { Percentage } \\
\text { of podophyllin } \\
\text { dry substance }\end{array}$ & $\begin{array}{l}\text { Percentage } \\
\text { of weight } \\
\text { of solution }\end{array}$ & $\begin{array}{l}\text { Percentage } \\
\text { of podophyllin } \\
\text { dry substance }\end{array}$ \\
\hline $\begin{array}{l}\text { Quercetin } \\
\text { Kaempherol } \\
\text { Podophyllotoxin } \\
\text { Dry substance }\end{array}$ & $\begin{array}{r}0.5 \\
1 \cdot 2 \\
2 \cdot 8 \\
20 \cdot 1\end{array}$ & $\begin{array}{r}2 \cdot 5 \\
6 \cdot 0 \\
13 \cdot 8 \\
100 \cdot 0\end{array}$ & $\begin{array}{r}0.8 \\
1.3 \\
2.6 \\
20.5\end{array}$ & $\begin{array}{r}3 \cdot 8 \\
6 \cdot 4 \\
12 \cdot 8 \\
100 \cdot 0\end{array}$ & $\begin{array}{r}0.6 \\
1.3 \\
2.6 \\
20.0\end{array}$ & $\begin{array}{r}3 \cdot 0 \\
6 \cdot 3 \\
12 \cdot 7 \\
100 \cdot 0\end{array}$ \\
\hline
\end{tabular}


phyllin. Kaempherol makes up about $6 \%$ of the dry substance of podophyllin. About $13 \%$ of the amount of dry substance was identified as podophyllotoxin. Two batches of podophyllin (no. 1-2, table) had nearly identical amounts of podophyllotoxin, whereas batch no. 3 had a $10 \%$ higher concentration of the active principle.

\section{Discussion}

This study has documented that approximately $10 \%$ of the amount of dry substance in podophyllin is made up of the two very mutagenic flavonols, namely quercetin and kaempherol. Podophyllotoxin accounts for about $13 \%$ of the weight, but the major part of the remaining $75 \%$ of the dry substance is made up by decomposition products of podophyllotoxin, peltatins and substances which have never been identified.

Quercetin has previously been extracted from podophyllin by simplified methods with yields of $2,4 \%$ (American podophyllin) ${ }^{7}$ and $1 \cdot 3 \%$ (Indian podophyllin). ${ }^{10} \mathrm{Kaempherol} \mathrm{has}$ to our knowledge never previously been isolated from podophyllin.

Although quercetin is mutagenic in bacteria and insects and caused gene conversion in yeast and chromosomal anomalies in cultured cells $^{8}$ equivocal results were obtained in animal carcinogenicity studies. ${ }^{8}$ Kaempherol has been shown to be mutagenic in bacteria and insects and in mammalian cells in vitro. ${ }^{9}$ It also induces micronuclei in mice. ${ }^{9}$ Quercetin and kaempherol occurs in plants as various glycosides which are not mutagenic. These may, however, hydrolyse to mutagenic aglycones by beta-glycosidases present in the mammalian intestinal flora. ${ }^{11}$ The suspected contribution of flavonoids to the induction of cancer is supported by the fact that cattle infected with bovine papillomavirus develop lung cancer after feeding with fern containing large amounts of quercetin. ${ }^{12}$ An epidemiological study shows a direct correlation between the incidence of cancer of the stomach in different parts of Japan and the content of quercetin and rhamnetin in local types of pickles. ${ }^{13}$

Infection with human papillomavirus (HPV) is known to be associated with genital neoplasia ${ }^{14}$ and treatment of HPV-induced lesions with a potentially mutagenic substance, such as podophyllin, may be a matter of concern. Treatment of genital warts with podophyllin can induce histologic changes including increase in the number of mitotic figures and necrosis in warts tissue. ${ }^{15}$ These changes in no way simulate those of squamous cell carcinoma. ${ }^{15}$ It should therefore be emphasised that at presence there are no data to support that podophyllin should act as a co-carcinogen in HIV-infected patients.

An alternative to podophyllin is self-application of a purified podophyllotoxin $0.5 \%$ solution (Condyline, Condylox). ${ }^{16}$ Podophyllotoxin can be used in both women and men with externally located genital warts. ${ }^{16} 17$
This topical preparation does not contain flavonoids and in the AMES test for mutagenesis, podophyllotoxin was found to be a nonmutagen. ${ }^{18}$ In a mitotic chromosomal abberation test podophyllotoxin induced micronuclei in the bone marrow of mice (personal communication, Nycomed-DAK, Denmark). ${ }^{11}$ This is not surprising as it is known that podophyllotoxin causes mitotic arrest, which is the basis of its therapeutic activity in genital warts. In addition prolonged topical application of podophyllotoxin is without carcinogenic activity in mice. ${ }^{19}$

To replace podophyllin another approach could be the use of purified higher-concentrated solutions of podophyllotoxin. A 5\% podophyllotoxin solution applied once weekly has been shown to be as effective and safe as podophyllin $20 \%$ in a controlled clinical trial in patients with genital warts. ${ }^{20}$ If a high-concentrated purified podophyllotoxin solution was developed and licensed it could with advantage replace the marketed podophyllin.

I thank Jana Hellman and Kim Kjørnaes, Nycomed-DAK, Denmark for technical assistance.

Kaplan IW. Condyloma acuminata. New Orleans Med Surg f 1942;42:388-90.

2 Krogh $G$ von. Topical treatment of penile condyloma acuminata with podophyllin, podophyllotoxin and colchicine. Acta Dermato-venereol 1978;58:163-8.

3 Krogh G von. Podophyllotoxin for condyloma acuminata eradication. Clinical and experimental studies on podophyllin lignans, colchicine and 5-fluorouracil. Acta phyllin lignans, colchicine and 5-

4 Kelly MG, Hartwell JL. The biological effects and the chemical composition of podophyllin. A review. 7 Natl Cancer Inst 1954;14:967.

5 Hartwell JL, Detty WE. Components of podophyllin. Isolation of and-peltatin. Structure Studies. $₹ \mathrm{Am} \mathrm{Chem}$ Soc 1950;72:246-53

6 Podwyssotzki V. Pharmakologische studien über podophyllum peltatum. Arch Exp Path Pharmakol 1880 13:29-53.

7 Umney JC. Podophyllum emodi. Pharm $f$ Trans 1892; 23:207-10.

8 Quercetin. IARC monographs on the evaluation of the carcinogenic risk of chemicals to humans. WHO, 1983; 31:213-27.

9 Kaempherol. IARC monographs on the evaluation of the carcinogenic risk of chemicals to humans. WHO 1983;31:171-8

10 Seshadri TR, Subramanian SS. Components of Indian podophyllum. $\mathcal{F}$ Sci Indian Res 1950;9B:137-41.

11 Brown JP, Dietrich PS. Mutagenicity of plant flavonols in the Salmonella/mammalian microsome test. Activation of flavonol glycosides by mixed glycosidases from rat cecal bacteria and other sources. Mutation Res 1979;66:223-40.

12 Campo MS. Papillomas and cancer in cattle. Cancer Surv 1987;6:39-45

13 Takenaka S, Sera N, Toluwa $\mathrm{H}$, et al. Identification of mutagens in Japanese pickles. Mutat Res 1989;223: mutagens.

14 Hausen $\mathrm{H}$ zur. Human papillomavirus and their possible role in squamous cell carcinomas. Curr Top Microbiol Immun 1977;23:191-7.

15 Wade TR, Acherman AB. The effects of resin of podophyllin on condyloma acuminatum. Am $\mathcal{f}$ Dermatopathol 1984;6:109-22.

16 Greenberg MD, Rutledge LH, Reid R, et al. A doubleblind, randomized trial of $0.5 \%$ podofilox and placebo for the treatment of genital warts in women. Obstet Gynecol 1991;77:735-9.

17 Beutner KR, Friedman-Kien AE, Artman NN, et al. Patient-applied podofilox for treatment of genital warts. Lancet 1989;ii:831-4.

18 Beutner KR. Podophyllotoxin in the treatment of genital human papillomavirus infection: A review. Semin Dermatol 1987;6:10-8.

19 Berenblum I. The effect of podophyllotoxin on the skin of the mouse with reference to carcinogenic action. $\mathcal{F}$ Natl Cancer Inst 1951;11:839-941.

20 Petersen CS, Kroon S, Worm AM, et al. Podophyllotoxin $5 \%$ and podophyllin $20 \%$ in the treatment of ano-genital warts. A double-blind comparative study. Eur $\mathcal{F}$ Sex Trans Dis 1985;2:155-8. 